\title{
Prenatal stress induces long-lasting effects in lung glucocorticoid receptor gene expression in a sex-dependent manner
}

\author{
O estresse pré-natal induz efeitos de longo prazo na expressão gênica de receptores \\ de glicocorticoides no pulmão de uma maneira dependente do sexo
}

\author{
Carolina Luft (D) 1凶, Natália Evangelista Campos (D) 1, Mauro Henrique Moraes Vargas (D) 2, \\ Márcio Vinícius Fagundes Donadio (D) 1 \\ Pontifícia Universidade Católica do Rio Grande do Sul, Laboratory of Pediatric Respirology. Porto Alegre, Rio Grande do Sul, Brazil. \\ 2 CNEC. Santo Ângelo, Rio Grande do Sul, Brazil.
}

How to cite this article:

Luft C, Campos NE, Vargas MHM, Donadio MVF. Prenatal stress induces long-lasting effects in lung glucocorticoid receptor gene expression in a sex-dependent manner. Sci Med. 2019;29(1):e33192. https://doi.org/10.15448/1980-6108.2019.1.33192

\section{ABSTRACT}

AIM: Stressful events during pregnancy may influence respiratory system development, resulting in long-term effects in the offspring. However, little is known on its long-lasting effects upon the expression of important genes in the lungs. Thus, we aimed to evaluate the effect of two different prenatal stress paradigms on lung glucocorticoid receptor (GR) expression in adulthood.

METHODS: Pregnant BALB/c mice were divided into 3 groups: control (CON), prenatal stress from the second week of pregnancy (PNS1) and prenatal stress on the last week of pregnancy (PNS2). In both groups (PNS1 and PNS2), restraint stress was used. When adults, male and female offspring were submitted to 30 min of restraint stress. Lung gene expression of GR was evaluated.

RESULTS: There was a significant increase in GR expression in males (PNS1), under basal conditions. Restraint stress during adulthood significantly reduced GR expression in PNS1 and PNS2 males as compared to controls. No significant differences were found for females. CONCLUSION: Results indicate that prenatal stress from the second week of gestation modulates adult male mice GR expression in the lungs. Thus, fetal exposure to maternal stress from the second week of gestation seems to modulate mechanisms responsible for pulmonary development in a sex-dependent manner.

KEYWORDS: Prenatal stress; Lung; Glucocorticoid receptor.

\section{RESUMO}

OBJETIVO: Eventos estressores durante a gestação podem influenciar o desenvolvimento do sistema respiratório, resultando em efeitos a longo prazo na prole. No entanto, pouco se sabe sobre seus efeitos duradouros sobre a expressão de genes importantes nos pulmões. Assim, nosso objetivo foi avaliar o efeito de dois diferentes modelos de estresse pré-natal na expressão pulmonar do receptor de glicocorticoide (GR) na vida adulta.

MÉTODOS: Camundongos BALB/c prenhes foram divididas em 3 grupos: controle (CON), estresse pré-natal a partir da segunda semana de gestação (PNS1) e estresse pré-natal durante a última semana de gestação (PNS2). Nos dois grupos (PNS1 e PNS2), o estresse por contenção foi utilizado. Quando adultas, as proles machos e fêmeas foram submetidas ao estresse por contenção durante 30 min. A expressão do gene GR no pulmão foi avaliada.

RESULTADOS: Houve um aumento significativo na expressão de GR em machos (PNS1) sob condições basais. O estresse na vida adulta reduziu significativamente a expressão de GR em machos PNS1 e PNS2 em comparação aos controles. Não foram encontradas diferenças significativas em fêmeas.

CONCLUSÃO: Os resultados indicam que o estresse pré-natal a partir da segunda semana de gestação modula a expressão do GR nos pulmões de camundongos machos adultos. Assim, a exposição fetal ao estresse materno a partir da segunda semana de gestação parece modular os mecanismos responsáveis pelo desenvolvimento pulmonar de uma maneira dependente do sexo.

DESCRITORES: Estresse pré-natal; Pulmão, Receptor de glicocorticoide 
Abbreviations: ANOVA, two-way analysis of variance; cDNA, complementary DNA; CeMBE, Center of Biological and Experimental Models; GAPDH, glyceraldehyde-3-phosphate dehydrogenase; GR, glucocorticoid receptors; HPA, hypothalamicpituitary-adrenal axis; mRNA, messenger RNA; PND, postnatal day; PNS, prenatal stress; PUCRS, Pontificia Universidade Católica do Rio Grande do Sul; SEM, standard error of the mean.

\section{INTRODUCTION}

The gestational period is well recognized for its plasticity and sensibility. Stressful events during pregnancy can influence fetal development, resulting in long-term effects in the offspring $[1,2]$. Thus, in adults, prenatal stress is related to neuroendocrine and metabolic diseases such as anxiety and obesity, among others. One potential mechanism that could explain early life programming is the activation of the hypothalamic-pituitary-adrenal axis (HPA) and, as a consequence, an increase of glucocorticoids in utero $[3,4]$.

During the respiratory system development in utero, glucocorticoids are key factors for fetal development, such as alveolar maturation and production of surfactant [5,6]. Therefore, disturbances during this period may modulate lung development. We have recently shown, in BALB/c mice, that prenatal stress improved female adulthood lung function and inflammatory parameters in an asthma model, in a sex-specific manner [7]. On the other hand, studies with mammals have reported that exposure to maternal glucocorticoids, due to prenatal stress, may generate deleterious effects in the lung, as reduced lung function, increased lung inflammation and airway hyperreactivity [8-11]. Nonetheless, mechanisms related to lung glucocorticoid exposure of the offspring during gestation have not yet been well elucidated, although it is well known that glucocorticoid receptors (GR) function is fundamental for the maintenance of several physiological effects $[6,12]$.

Prenatally stressed mice exhibit a reduced expression of GR in the hippocampus, resulting in an attenuated feedback response and increased HPA activity, promoting an increase in corticosterone secretion in adult life [13]. Thus, GR are important regulators of the HPA axis and alterations in the gene expression of this receptor may culminate in different stress-associated diseases [14]. Although the relationship of gestational stress with the decrease in
GR expression in offspring hippocampus has been well established, it has already been shown that glucocorticoid exposure generates an increase of this receptor in other regions, such as the adipose tissue and liver in rats [15].

Although prenatal stress can lead to structural and functional alterations in adult lung function, little is known on its long-lasting effects upon the expression of GR in the lungs. Thus, we hypothesized that GR expression in the lungs are modulated by early life stress in a long-lasting manner. The present study aimed to evaluate the effect of two different prenatal stress paradigms on lung GR expression in adulthood. Response to restraint stress in adulthood and possible sexual differences were also evaluated.

\section{METHODS}

\section{Animals}

Male and female BALB/c mice were acquired from the Center of Biological and Experimental Models (CeMBE), from Pontificia Universidade Católica do Rio Grande do Sul (PUCRS). Mice were kept in a vivarium under controlled lighting (12h light: $12 \mathrm{~h}$ darkness cycle) with free access to food and water. All animal procedures were performed in accordance with the guidelines described in the Guide for the Care and Use of Laboratory Animals. The study was approved by the University Ethics Committee in Animal Use under registry number 11/00270.

\section{Experimental design}

Adult BALB/c primiparous females were mated with a male and after identification of the pregnancy, through the presence of a vaginal plug, were divided into three groups as shown in Figure 1B: control, prenatal stress 1 (PNS1) and prenatal stress 2 (PNS2). After weaning at day 21 (PND21), male and female offspring from the experimental groups were separated into boxes and maintained with isolated and individual ventilation until adulthood (PND60). In order to evaluate the response to restraint stress in adulthood, animals from the three experimental groups were further divided into two groups: baseline or subjected to a restraint stress for 30 minutes, and immediately euthanized for the quantification of glucocorticoid receptor gene expression using real-time PCR The experimental design is shown in Figure 1A. 

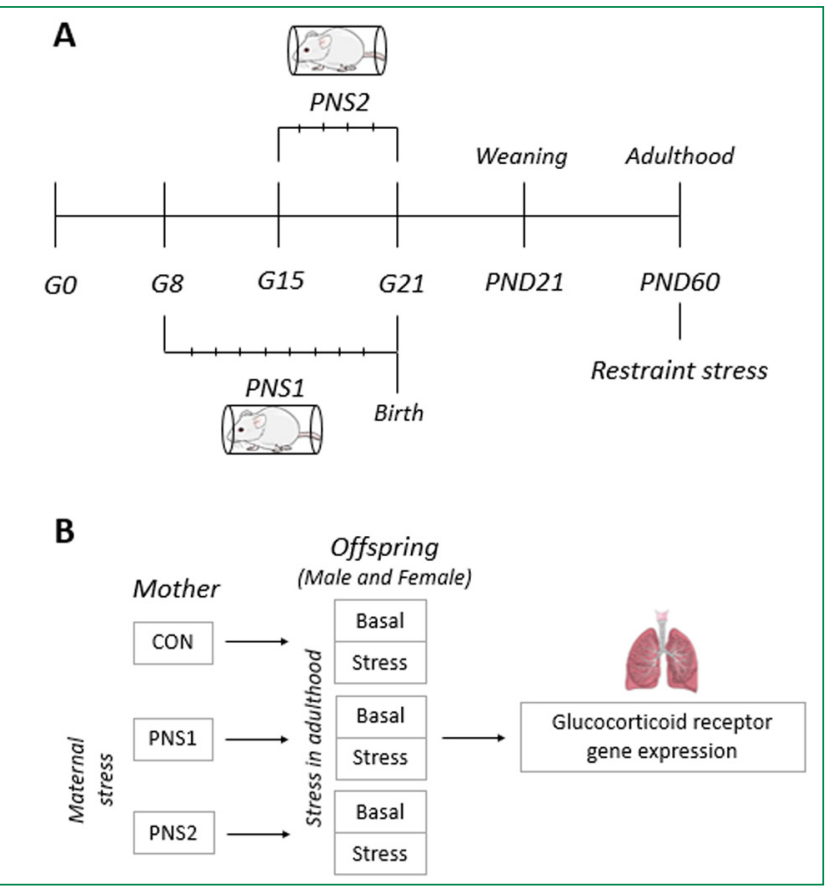

Figure 1. Study design and experimental groups. Experimental design of the study (A) and diagram representing the experimental groups (B). PNS1: prenatal stress from the second week of pregnancy; PNS2: prenatal stress at the last week; GO: gestational day 0; G8: gestational day 8; G15: gestational day 15; G21: gestational day 21; PND21: post-natal day 21. PND60: post-natal day 60.

\section{Prenatal stress}

Restraint stress was performed using a ventilated crystal acrylic container (Insight, Brazil) for $30 \mathrm{~min}$. Pregnant females from PNS1 group were submitted to the stress protocol from the 8th day of the gestational period (second week) until birth, every other day. Females from PNS2 group were submitted to stress from the 14th day of pregnancy (last week), every day until parturition. The control group was not submitted to any intervention during the gestational period [7].

\section{Stress in adulthood}

Restraint stress in adulthood (PND60) was performed using the same apparatus described above, for $30 \mathrm{~min}$. Afterwards, animals were anesthetized, euthanized and had their lungs removed.

\section{Quantification of mRNA by real-time PCR}

Total cellular lung RNA was extracted by the

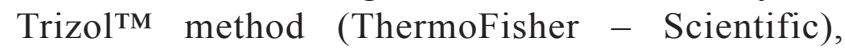
according to the manufacturer's instructions. The
RNA was resuspended in $20 \mu \mathrm{L}$ of nuclease-free water (Ambion ${ }^{\mathrm{TM}}$ ) and converted into complementary DNA (cDNA) (GoScript ${ }^{\mathrm{TM}}$ Reverse Transcription System Protocol - Promega) according to the protocol indicated by the manufacturer. The final concentration of cDNA was analyzed by fluorometric method (Qubit ${ }^{\mathrm{TM}}$ - ThermoFisher - Scientific) using a commercial kit (Qubit ${ }^{\mathrm{TM}}$ dsDNA HS Assay - ThermoFisher - Scientific). Gene expression was performed in real-time quantitative PCR (Step One Plus - Applied Biosystems), using 16 ng of cDNA. Lung samples were prepared in duplicate and the relative expression of messenger RNA (mRNA) was calculated by the Delta-delta $\mathrm{Ct}$ method $(\Delta \Delta \mathrm{Ct})$, adopting glyceraldehyde-3-phosphate dehydrogenase (GAPDH) as the endogenous reference gene. Negative control for each primer was used on each plate to check for possible contamination. Amplification reagent measurements were calculated based on the incorporation of the SYBR ${ }^{\mathrm{TM}}$ Green fluorescence marker (Applied Biosystems - ThermoFisher Scientific) into the double-stranded cDNA for each amplification reaction. The results represent the $\mathrm{x}$-fold increase of gene expression compared with the control group.

The set of primers specific for each gene were: GR (direct 5 'GGAATAGGTGCCAAGGGTCT 3'; reverse 5 'GAGCACACCAGGCAGAGTTT 3') and GAPDH (direct 5 'GGGGAGCCAAAAGGGTCATC 3'; reverse 5 'GACGCCTGCTTCACCACCTTCTTG 3').

\section{Statistical analysis}

Results are expressed as mean \pm standard error of the mean (SEM). Comparisons between groups were performed using a two-way analysis of variance (ANOVA), followed by the LSD posthoc test. Differences were considered significant when $p<0.05$. All analysis were performed using the software IBM SPSS Statistics 18.0 (Chicago, IL, USA).

\section{RESULTS}

The results have shown a significant interaction between the PNS group and the stress in adulthood on GR mRNA expression in males (Figure 2A). Under basal conditions, PNS1 group showed significantly increased expression of GR in the lungs when compared to both controls $(p<0.05)$ and PNS2 $(p<0.01)$ groups. Indeed, restraint stress in adulthood significantly $(p<0.01)$ decreased lung GR expression on PNS1 animals. In addition, when comparing PNS1 


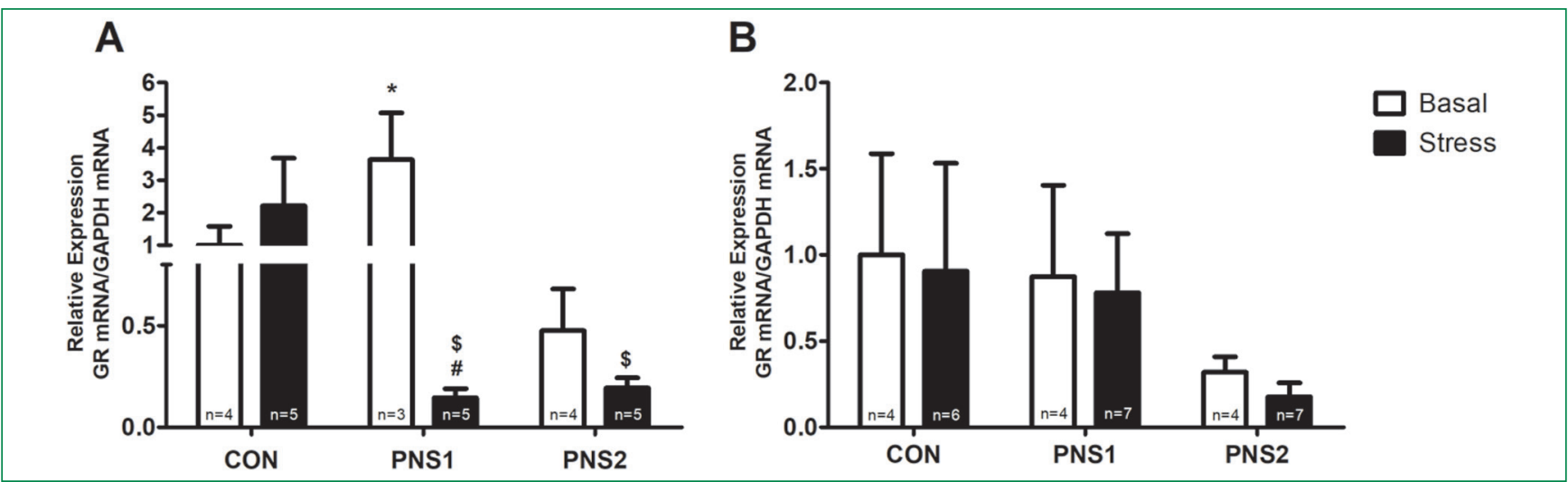

Figure 2. Effects of prenatal stress on glucocorticoid receptor expression in lung under basal conditions and after restraint stress in adulthood. Tissue glucocorticoid receptor mRNA was measured in males (A) and females (B). Values are shown as mean and standard error of the mean. * significant difference $(p<0.05)$ when comparing PNS1 basal group vs. control basal and PNS2 basal groups; ${ }^{\$}$ significant difference $(\mathrm{p}<0,05)$ when comparing PNS1 stress and PNS2 stress groups vs. control stress group; \#significant difference $(p<0,05)$ when comparing PNS1 stress group vs. PNS1 basal group. CON: control; PNS1: prenatal stress induced from the second week of pregnancy until birth; PNS2: prenatal stress induced on the last week of pregnancy.

and PNS2 stress groups to the control stress group, a significant $(\mathrm{p}<0.05)$ reduction of GR expression was observed. On the other hand, no significant differences were found between groups for females, as shown in Figure 2B.

\section{DISCUSSION}

Adverse events during gestation can generate longlasting programming effects that remain throughout life, although several mechanisms involving the action of peripheral glucocorticoids are still not well elucidated [16]. In this study, we have demonstrated, for the first time, the effects of maternal restraint stress on GR gene expression in the lungs. Our data suggest that prenatal stress generates permanent changes in GR expression in adult males, both at baseline and in response to restraint stress in adulthood, in an effect dependent on sex and timing of prenatal stress.

Our results demonstrate that PNS1 males had a higher expression of GR in the lungs under basal conditions. It is well established that corticosteroid receptors in adult life are influenced by fetal programming, as its expression is diminished in brain regions such as hippocampus [17]. Moreover, Maeyama et al have already demonstrated that prenatal stress promotes an increase in GR expression in the liver [18]. Stressor events during gestation may result in elevated levels of endogenous glucocorticoids, which reach the placental barrier and increase fetal exposure to maternal hormones [13]. Thus, we hypothesized that fetal exposure to maternal corticosterone from the second week of gestation, in association with the onset of pulmonary development (embryonic day 9), could modulate GR expression mechanisms. Interestingly, maternal stress in the last week of gestation (PNS2) did not promote significant changes, emphasizing that these effects are dependent on the intensity and timing of the stressor event. Our group has shown that prenatal stress from the second week of gestation (PNS1) causes changes in the HPA axis of the offspring, although a protective effect on lung inflammatory response was demonstrated specifically for females [7]. We speculate that pulmonary GR gene expression could be associated to that effect, as PNS adult males, in this study, presented an increased expression of the receptor and no attenuation on lung inflammatory response was seen in our previous asthma model. On the other hand, present data shows that PNS females present no alterations on lung GR expression compared to controls and a protective effect on lung function and inflammatory parameters was demonstrated after an ovalbumin-induced response in a previous study [7].

Early adverse experiences promote a decrease in the HPA negative feedback, leading to a hyperreactivity in response to stress in adult life $[19,20]$. Here, we have demonstrated that male offspring from mothers stressed during pregnancy, when subjected to restraint stress in adulthood, showed a decrease in lung GR gene expression. Green et al demonstrated that stress during pregnancy increases the sensitivity to stress in adulthood, decreasing the expression of GR in hippocampus and prefrontal cortex in rats [21]. During restraint stress, GR is occupied by increasing concentrations of corticosterone. In addition, in regions such as the hippocampus, receptors are downregulated 
on a glucocorticoid negative feedback response that increases HPA activity. Although that is well described for the brain, as far as we know, there is no evidence showing GR expression in the lungs in response to restraint stress in adulthood. Thus, it is possible to speculate that decreased receptor expression in PNS1 group, after restraint stress in adulthood, could be a result of a downregulation response.

Sexual differences associated with different regulatory mechanisms of the HPA were shown previously, as gonadal hormones are one of the main agents in the neuroendocrine responses to stress $[22,23]$. Generally, females are more sensitive to HPA axis activation and have higher basal corticosterone levels, possibly due to the oscillations of estradiol during the estrous cycle [24]. However, data in our study suggests a different response for the lungs, as the effects of stress during pregnancy were evident only in males. Sexspecific mechanisms on the effects of prenatal stress on adult life response to a stressor deserves further attention to help elucidate different sex vulnerabilities to lung diseases.

In conclusion, our results demonstrate that stress from the second week of gestation modulates adult male GR expression in the lungs, both at basal condition and after restraint stress in adulthood. These findings may be determinant for pulmonary development and possibly influence mechanisms responsible for the onset of respiratory diseases, although this hypothesis still needs to be tested. Moreover, the data presented here may provide additional information to further investigate sex-dependent mechanisms related to the effects of early-life stress in the lungs.

\section{NOTES}

\section{Acknowledgments}

The authors thank Conselho Nacional de Desenvolvimento Científico e Tecnológico - CNPq-Brasil (NEC and MHMV) and Coordenação de Aperfeiçoamento de Pessoal de Nivel Superior CAPES-Brasil (CL) for the concession of scholarships.

Funding

This study was financed in part by the Coordenação de Aperfeiçoamento de Pessoal de Nivel Superior - CAPES, Brasil - Finance Code 001.

Conflict of interest disclosure

The authors have no conflict of interests to declare.

Authors' contributions

The authors declare to have made substantial contributions to the conception, or design, or acquisition, or analysis, or interpretation of data; and drafting the work or revising it critically for important intellectual content; and to approve the version to be published.

Availability of data and responsibility for the results

The authors declare to have had full access to the available data and they assume full responsibility for the integrity of these results.

\section{REFERENCES}

1. McGowan PO, Matthews SG. Prenatal Stress, Glucocorticoids, and Developmental Programming of the Stress Response. Endocrinology. 2018;159(1):69-82. https://doi.org/10.1210/en.2017-00896

2. Weinstock M. The long-term behavioural consequences of prenatal stress. Neuroscience and biobehavioral reviews. 2008;32(6):1073-86. https://doi.org/10.1016/j.neubiorev.2008.03.002

3. Boersma GJ, Tamashiro KL. Individual differences in the effects of prenatal stress exposure in rodents. Neurobiol Stress. 2015;1:100-8. https://doi.org/10.1016/j.ynstr.2014.10.006

4. Worthman CM, Kuzara J. Life history and the early origins of health differentials. American journal of human biology: the official journal of the Human Biology Council. 2005;17(1):95-112. https://doi.org/10.1002/ajhb.20096

5. Bolt RJ, van Weissenbruch MM, Lafeber HN, Delemarre-van de Waal HA. Glucocorticoids and lung development in the fetus and preterm infant. Pediatr Pulmonol. 2001;32(1):76-91. https://doi.org/10.1002/ppul.1092

6. Moisiadis VG, Matthews SG. Glucocorticoids and fetal programming part 1: Outcomes. Nature reviews Endocrinology. 2014;10(7):391-402. https://doi.org/10.1038/nrendo.2014.73

7. Vargas MH, Campos NE, de Souza RG, da Cunha AA, Nuñez NK, Pitrez PM, Donadio MV. Protective effect of early prenatal stress on the induction of asthma in adult mice: Sex-specific differences. Physiol Behav. 2016 Oct 15;165:358-64. https://doi.org/10.1016/j.physbeh.2016.08.023

8. Lee AG, Chiu YM, Rosa MJ, Cohen S, Coull BA, Wright RO, Morgan WJ, Wright RJ. Association of prenatal and early childhood stress with reduced lung function in 7-year-olds. Ann Allergy Asthma Immunol. 2017 Aug;119(2):153-9. https://doi.org/10.1016/j.anai.2017.05.025 
9. Barreto do Carmo MB, Righetti RF, Tibério IF, Hunziker MH. The effects of prenatal "psychological" stressor exposure on lung inflammation and hyperresponsiveness in adult rat offspring. Dev Psychobiol. 2016 Dec;58(8): 1076-86. https://doi.org/10.1002/dev.21441

10. Pincus-Knackstedt MK, Joachim RA, Blois SM, Douglas AJ, Orsal AS, Klapp BF, Wahn U, Hamelmann E, Arck PC. Prenatal stress enhances susceptibility of murine adult offspring toward airway inflammation. J Immunol. 2006;177(12):8484-92. https://doi.org/10.4049/jimmunol.177.12.8484

11. Weinstock M. The potential influence of maternal stress hormones on development and mental health of the offspring. Brain, behavior, and immunity. 2005;19(4):296-308. https://doi.org/10.1016/j.bbi.2004.09.006

12. Walker DJ, Spencer KA. Glucocorticoid programming of neuroimmune function. General and comparative endocrinology. 2018;256:80-8. https://doi.org/10.1016/j.ygcen.2017.07.016

13. Harris A, Seckl J. Glucocorticoids, prenatal stress and the programming of disease. Horm Behav. 2011;59(3):279-89.

14. Seckl JR. Prenatal glucocorticoids and long-term programming. European journal of endocrinology. $2004 ; 151$ Suppl 3, U49-62. https://doi.org/10.1530/eje.0.151u049

15. Nyirenda MJ, Lindsay RS, Kenyon CJ, Burchell A, Seckl JR. Glucocorticoid exposure in late gestation permanently programs rat hepatic phosphoenolpyruvate carboxykinase and glucocorticoid receptor expression and causes glucose intolerance in adult offspring. J Clin Invest. 1998;101(10):2174-81. https://doi.org/10.1172/jci1567

16. McGowan PO, Matthews SG. Prenatal Stress, Glucocorticoids, and Developmental Programming of the Stress Response. Endocrinology. 2018; 1;159(1):69-82. https://doi.org/10.1210/en.2017-00896

17. Kapoor A, Dunn E, Kostaki A, Andrews MH, Matthews SG. Fetal programming of hypothalamo-pituitaryadrenal function: prenatal stress and glucocorticoids. J Physiol. 2006;572(Pt 1):31-44. https://doi.org/10.1113/ jphysiol.2006.105254

18. Maeyama H, Hirasawa T, Tahara Y, Obata C, Kasai H, Moriishi K, Mochizuki K, Kubota T. Maternal restraint stress during pregnancy in mice induces 11 beta-HSD1-associated metabolic changes in the livers of the offspring. J Dev Orig Health Dis. 2015 Apr;6(2):105-14. https://doi.org/10.1017/s2040174415000100

19. Brunton PJ, Russell JA. Prenatal social stress in the rat programmes neuroendocrine and behavioural responses to stress in the adult offspring: sex-specific effects. J Neuroendocrinol. 2010;22(4):258-71. https://doi.org/10.1111/ j.1365-2826.2010.01969.x

20. Baquedano E, Garcia-Caceres C, Diz-Chaves Y, Lagunas N, Calmarza-Font I, Azcoitia I, Garcia-Segura LM, Argente J, Chowen JA, Frago LM. Prenatal stress induces long-term effects in cell turnover in the hippocampushypothalamus-pituitary axis in adult male rats. PLoS One. 2011;6(11):e27549. https://doi.org/10.1371/journal. pone. 0027549

21. Green MK, Rani CS, Joshi A, Soto-Piña AE, Martinez PA, Frazer A, Strong R, Morilak DA. Prenatal stress induces long term stress vulnerability, compromising stress response systems in the brain and impairing extinction of conditioned fear after adult stress. Neuroscience. 2011;192:438-51. https://doi.org/10.1016/j. neuroscience.2011.06.041

22. Seale JV, Wood SA, Atkinson HC, Harbuz MS, Lightman SL. Gonadal steroid replacement reverses gonadectomyinduced changes in the corticosterone pulse profile and stress-induced hypothalamic-pituitary-adrenal axis activity of male and female rats. J Neuroendocrinol. 2004;16(12):989-98. https://doi.org/10.1111/j.1365-2826.2004.01258.x

23. Iwasaki-Sekino A, Mano-Otagiri A, Ohata H, Yamauchi N, Shibasaki T. Gender differences in corticotropin and corticosterone secretion and corticotropin-releasing factor mRNA expression in the paraventricular nucleus of the hypothalamus and the central nucleus of the amygdala in response to footshock stress or psychological stress in rats. Psychoneuroendocrinology. 2009;34(2):226-37. https://doi.org/10.1016/j.psyneuen.2008.09.003

24. Handa RJ, Weiser MJ. Gonadal steroid hormones and the hypothalamo-pituitary-adrenal axis. Front Neuroendocrinol. 2014;35(2):197-220. 